\title{
Studies on Storability of Elite Hybrids of Sunflower
}

\author{
J.A. Surekha*, Vijaykumar Kurnalliker, N.M. Shakuntala, Vikas Kulkarni, \\ S.M. Prashant and Mukesh Kumar Meena
}

Department of Seed Science and Technology, UAS Raichur, 584104, Karnataka, India

*Corresponding author

\section{Keywords}

Sunflower,

Genotypes,

Container, Vigour, Quality, EC

\section{Article Info}

Accepted: 12 September 2018 Available Online: 10 October 2018

\section{A B S T R A C T}

Sunflower (Helianthus annuиs L.) is one of the principal oil seed crops of the world. Deterioration in seed quality is reflected in terms of loss in vigour and viability of seeds. Therefore, seed viability and vigour largely depends on the storage conditions, seed treatment and packaging materials used to store the seeds. With this background storage experiment was carried out in laboratory of Department of Seed Science and Technology in two factorial completely randomized design to assess the quality of four sunflower genotypes such as RSFH-130, RSFH-1887, KBSH- 53 and KBSH- 44 which were stored in two different packaging materials such as cloth bag and polythene bag (700 guage) for a period of 10 months and observation were taken bimonthly. In the present study the results revealed that RSFH- 1887 and stored in polythene bag maintained highest germination $(80.25 \%)$ and vigour (1559) respectively which was followed by KBSH-53 stored in polythene bag maintained germination $(79.85 \%)$ and vigour $(1518)$ at the end of $10^{\text {th }}$ month. Whereas, KBSH - 44 stored in polythene bag was intermediate storer which showed germination of $(77.76 \%)$ and vigour $(1430)$ at the end of $10^{\text {th }}$ month. While, RSFH- 130 stored in cloth bag was found to be a poor storer which showed reduced germination $(57.26 \%)$ and vigour (907) compared to other genotypes at the end of $10^{\text {th }}$ month. Whereas, electrical conductivity was found to be less in RSFH-1887 stored in polythene bag $\left(0.72 \mathrm{dSm}^{-1}\right)$ and highest EC was found in RSFH-130 stored in cloth bag $\left(0.85 \mathrm{dSm}^{-1}\right)$ since it is inversely proportional to seed quality. However, the seed stored in cloth bag showed less germination and vigour compared to polythene bags irrespective of genotypes. It can be concluded that RSFH- 1887 stored in polythene bag maintained high seed quality. Thus the experiment helps in identifying best genotype among the above four genotypes and best container for better storability.

\section{Introduction}

Sunflower (Helianthus annuus L.) is one of the most important oil seed crops of the world. It belongs to the family Asteraceae bearing a basic chromosome number of 17 . The native of sunflower is found to be southern parts of USA and Mexico. Sunflower ranks third, next to groundnut and soybean in total production. The crop is well adopted because of attributes such as short duration, photoperiod insensitivity, adoptability to wide range of soil and climatic conditions, drought tolerance, higher seed multiplication ratio $(1: 50)$ having high percentage of edible oil (45-50\%). In India, during 2016-17, the area under 
sunflower cultivation was 0.344 million ha, with a total annual production of 0.24 million tonnes and productivity of $699 \mathrm{~kg}$ ha-1(Anon., 2017). In Karnataka, the area under sunflower is 0.22 million ha, with total production of 0.10 million tonnes and productivity of $458 \mathrm{~kg}$ $\mathrm{ha}^{-1}$ (Anon., 2017) and occupies first position recognized as "Sunflower State" in the oilseeds scenario of the country. Seed being a biological or living entity, deterioration in its quality occurs with the advancement in ageing, which is common for all the living organisms. However, it varies with genotype to genotype as the shelf-life of seed is determined and accomplished, to a large extent, by the chemical composition. Seeds with high oil content like sunflower appear to loose their germination and vigour in short period of time despite precautions taken during harvesting and drying. High temperature and relative humidity cause rapid deterioration of viability and vigour of crop seeds, thus the existing environmental condition affect the seed quality and storability. Seeds of agricultural crops including hybrid sunflower belong to micro biotic group. Further, Ewart (1908) opined that fairly cool and dry conditions preserve seeds for longer time. Under tropical situation seed deterioration has become the most inevitable unless the seeds are dried and packed in suitable container. The relative high cost of the seed material and importance of retaining their quality for next season justify the selection of proper packaging strategy. With this background, the present study is carried out to assess the impact of different genotypes and packaging materials on storability of sunflower seeds.

\section{Materials and Methods}

\section{Source of Seed}

The seeds of sunflower hybrid RSFH-1887 and RSFH-130 were procured from sunflower scheme Main Agricultural Research Station, University of agricultural sciences, Raichur. The seeds of sunflower hybrid KBSH-44 and KBSH-53 were procured from Seed unit, University of agricultural sciences, Raichur and University of agricultural sciences Bangalore, respectively.

\section{Design and layout}

The experiment was laid out in FCRD (Factorial completely randomised design) two factors with three replications and eight treatment combinations.

\section{Treatment details}

\section{Factor-I- Genotypes (G)}

$\mathrm{G}_{1}:$ RSFH-130

$\mathrm{G}_{2}$ : RSFH-1887

$\mathrm{G}_{3}$ : KBSH-53

$\mathrm{G}_{4}: \mathrm{KBSH}-44$

\section{Factor-II-Containers (C)}

$\mathrm{C}_{1}-$ Cloth bag

$\mathrm{C}_{2}$ - Polythene bag (700 guage).

\section{Treatment combinations}

$\mathrm{G}_{1} \mathrm{C}_{1}$ : RSFH- 130 stored in cloth bag $\mathrm{G}_{1} \mathrm{C}_{2}$ : RSFH- 130 stored in polythene bag $\mathrm{G}_{2} \mathrm{C}_{1}$ : RSFH- 1887 stored in cloth bag $\mathrm{G}_{2} \mathrm{C}_{2}$ : RSFH- 1887 stored in polythene bag $\mathrm{G}_{3} \mathrm{C}_{1}$ : KBSH- 53 stored in cloth bag $\mathrm{G}_{3} \mathrm{C}_{2}$ : KBSH- 53 stored in polythene bag $\mathrm{G}_{4} \mathrm{C}_{1}$ : KBSH -44 stored in cloth bag $\mathrm{G}_{4} \mathrm{C}_{2}$ : KBSH - 44 stored in polythene bag.

\section{Observations to be recorded bimonthly}

\section{Germination (\%)}

The germination test was conducted in the laboratory using between paper methods as 
per ISTA (1999). One hundred seeds of four replicates were placed equidistantly between moist paper towels. The rolled towels were placed in the germination chamber, where 25 $\pm 1^{\circ} \mathrm{C}$ and 90 per cent $\mathrm{RH}$ were maintained. The seedlings were evaluated on eighth day of incubation and the cumulative percentage of germination was expressed based on normal seedlings. (ISTA, 1999).

Seed Germination $(\%)=\frac{\text { Number of normal seedings }}{\text { Total number of seeds }} \times 100$

\section{Seedling vigour index I}

The seedling vigour index was computed by adopting the formula given by Abdul-Baki and Anderson (1973) and expressed in whole number.

Seedling vigour index $\mathrm{I}=$ Germination $(\%) \mathrm{x}$ Mean seedling length $(\mathrm{cm})$

\section{Electrical conductivity $\left(\mathrm{dSm}^{-1}\right)$}

Three replicates of 5 grams of seeds each were taken at random from each sample and washed with distilled water three to four times to. Then they were soaked in $25 \mathrm{ml}$ of distilled water at $25 \pm 1^{\circ} \mathrm{C}$ for 24 hours. The leachate was decanted and the EC was measured with Digital conductivity meter. The electrical conductivity of the seed leachate was measured in the digital conductivity bridge (ELICO) with a cell constant 1.0 and the mean values were expressed in deci simons per meter (dSm-1) (Milosevic et al., 2010).

\section{Statistical analysis}

The mean data of the laboratory experiments were statistically analyzed by adopting appropriate statistical methods as outlined by Panse and Sukhatme (1967). The critical differences were calculated at one per cent level of probability wherever ' $F$ ' test was found significant for various seed quality parameters under study. The percentage data were transformed into arcsine root transformation wherever it was applicable prior to the statistical analysis.

\section{Results and Discussion}

\section{Seed germination $(\%)$}

The data recorded on seed germination as influenced by different hybrids, packaging materials and their interaction are presented in Table 1. mean germination declined significantly with seed aging irrespective of the treatments from initial $(95.69 \%)$ to $(73.77$ $\%)$ at the end of 10 months.

\section{Genotypes (G)}

Seed germination differed significantly between the genotypes during storage. In the $2^{\text {nd }}$ month of storage, significantly higher germination (96.13\%) was seen in RSFH$1887\left(\mathrm{G}_{2}\right)$ which was followed by KBSH-53 (96.07 \%).Whereas, RSFH-130 showed lesser germination of 95.26 per cent. The similar trend was followed throughout the storage experiment. At the end of 10 months highest germination was seen in $\mathrm{G}_{2}(78.20 \%)$ which was followed by $\mathrm{G}_{3}(77.60 \%)$ and $\mathrm{G}_{4}(75.50$ $\%)$, the lowest seed germination was observed in $\mathrm{G}_{1}(63.67 \%)$. The genotypes in polythene bag showed significantly higher germination compared to seeds stored in cloth bag. Sunflower hybrids recorded lower germination percentage which might be attributed to variation among genotypes in withstanding environmental condition and the result is in consonance with findings of Shelar et al., (2008) that decline of germination is much more acute under tropical conditions. The observed reduction in percentage seed germination over time could also be linked to the reduction in enzyme activity within the seed and with the reduction in germination 
percentage there is reduction in all the seed quality parameters, Iqbal et al., (2002), Ruzrokh et al., (2003), and Demirkaya et al., (2010).

\section{Containers (C)}

There was a significant variation among the storage containers for seed germination throughout the storage period irrespective of containers. At second month of storage, maximum germination percentage was recorded by $\mathrm{C}_{2}(96.46 \%)$ and minimum germination was recorded in $\mathrm{C}_{1}$ (94.92), the same trend was followed till 10 months of storage. At the end of 10 months the seeds stored in polythene bag $\left(\mathrm{C}_{2}\right)$ recorded highest germination of 76.98 per cent and seeds stored in cloth bag $\left(\mathrm{C}_{1}\right)$ showed minimum germination of 70.57 per cent. The germination and seedling vigour were significantly higher in sunflower seed stored in moisture impervious containers when compared to moisture pervious containers throughout the storage period. Decline in germination percentage with advance in storage period, may be attributed to aging effect, leading to depletion of food reserves and decline in synthetic activity of embryo apart from loss of viability and storage condition and might be development of storage fungi which resulted in poor performance in seed stored in cloth bag (Tekrony et al., 1993). Superiority of Polythene over cloth bag in prolonging the storage life was reported by Bhattacharya et al., 1983 and Ankaiah et al., 2006 in sunflower and Mote et al., 1995 in Sorghum.

\section{Interaction between genotypes and containers: $(\mathbf{G} \times \mathbf{C})$}

Interaction between Genotypes and Containers differed significantly in all the months of storage except for $2^{\text {nd }}$ month. In the second month, $\mathrm{G}_{2} \mathrm{C}_{2}$ depicted highest germination of
96.92 per cent followed by $\mathrm{G}_{3} \mathrm{C}_{2}(96.69 \%)$ and $\mathrm{G}_{4} \mathrm{C}_{2}(96.07 \%) . \mathrm{G}_{1} \mathrm{C}_{1}(94.46 \%)$ showed minimum germination compared to other treatments. Similar trends were followed till 10 months of storage. At the end of storage period RSFH-130 in cloth bag $\left(\mathrm{G}_{1} \mathrm{C}_{1}\right)$ showed least germination (57.26 \%) and RSFH-1887 stored in polythene bag $\left(\mathrm{G}_{2} \mathrm{C}_{2}\right)$ maintained maximum germination of 80.25 per cent. The differences in germination percentage among the genotypes may be due to varietal differences in the seed chemical composition and its ability to withstand the differences in the environmental conditions and same as reported by Natraj, 2008 in sunflower, Simic et al., 2006 in maize, soybean and sunflower and Reuzeau and Cavalie (1995) in sunflower seeds.

\section{Seedling vigour index}

The effect of genotypes packaging materials and their interaction effects on seedling vigour index I are discussed in Table 2. Generally the mean seedling vigour index declined from 2532 to 1308 at the end of 10 months.

\section{Genotypes (G)}

Seedling vigour index I differed significantly among all the months irrespective of the genotypes. Initially highest seedling vigour index $I$ was seen in $G_{2}$ (2620) which was followed by $\mathrm{G}_{3}$ (2600) and $\mathrm{G}_{4}$ (2489) and lowest in $\mathrm{G}_{1}$ (2418).

The same order was followed upto 10 months of storage where, $G_{2}$ maintained highest vigour of 1443 which was followed by $\mathrm{G}_{3}$ (1408) and least vigour index I was found in $\mathrm{G}_{1}$ (1042). The differences in seedling vigour among the genotypes may be due to mechanical threshing method where the seeds may get damaged. This result is in good accordance with Muhammad et al., (2008), Sharma et al., (2006) 
Table.1 Effect of genotypes, containers and their interaction on germination percentage of sunflower hybrids during storage

\begin{tabular}{|c|c|c|c|c|c|}
\hline \multirow{3}{*}{ Treatment } & \multicolumn{5}{|c|}{ Germination percentage } \\
\hline & \multicolumn{5}{|c|}{ Storage period in months } \\
\hline & 2 & 4 & 6 & 8 & 10 \\
\hline \multicolumn{6}{|c|}{ Genotypes (G) } \\
\hline$\overline{\mathbf{G}_{1}}$ & $95.26(77.48)$ & $87.06(69.05)$ & $81.65(64.69)$ & $74.49(59.83)$ & $63.67(53.00)$ \\
\hline $\mathbf{G}_{2}$ & $96.13(78.70)$ & $90.89(72.47)$ & $84.92(67.20)$ & $82.71(65.49)$ & $78.20(62.19)$ \\
\hline$\overline{\mathbf{G}_{3}}$ & $96.07(76.64)$ & $89.17(70.85)$ & $84.57(66.86)$ & $81.57(64.60)$ & $77.60(61.82)$ \\
\hline $\mathbf{G}_{4}$ & $95.31(77.54)$ & $88.19(69.9)$ & $85.53(67.70)$ & $81.05(64.21)$ & $75.50(60.40)$ \\
\hline Mean & 95.69 & 88.83 & 84.17 & 79.95 & 73.77 \\
\hline S.Em \pm & 0.11 & 0.02 & 0.01 & 0.10 & 0.04 \\
\hline CD at $1 \%$ & 0.44 & 0.07 & 0.04 & 0.42 & 0.17 \\
\hline \multicolumn{6}{|c|}{ Containers (C) } \\
\hline$\overline{\mathrm{C}_{1}}$ & $94.92(77.00)$ & $86.80(68.75)$ & $82.38(65.21)$ & $76.91(61.39)$ & $70.57(57.3)$ \\
\hline $\mathrm{C}_{2}$ & $96.46(79.18)$ & $90.86(72.42)$ & $85.97(68.02)$ & $83(65.67)$ & $76.98(61.4)$ \\
\hline Mean & 95.69 & 88.83 & 84.17 & 62.26 & 73.77 \\
\hline S.Em \pm & 0.08 & 0.01 & 0.01 & 0.07 & 0.03 \\
\hline CD at $1 \%$ & 0.33 & 0.03 & 0.04 & 0.27 & 0.12 \\
\hline \multicolumn{6}{|c|}{ Interaction (G×C) } \\
\hline$\overline{\mathrm{G}_{1} \mathrm{C}_{1}}$ & $94.46(76.40)$ & $84.04(66.46)$ & $79.32(62.95)$ & $68.26(55.71)$ & $57.26(49.18)$ \\
\hline $\mathbf{G}_{1} \mathbf{C}_{2}$ & $96.07(78.57)$ & $90.08(71.46)$ & $84.01(66.43)$ & $80.73(63.96)$ & $70.08(56.84)$ \\
\hline $\mathbf{G}_{2} \mathbf{C}_{1}$ & $95.52(77.70)$ & $89.65(71.24)$ & $83.66(66.16)$ & $80.16(63.55)$ & $76.15(60.77)$ \\
\hline $\mathrm{G}_{2} \mathrm{C}_{2}$ & $96.92(79.90)$ & $92.13(73.71)$ & $87.90(69.67)$ & $85.26(67.43)$ & $80.25(63.62)$ \\
\hline $\mathrm{G}_{3} \mathrm{C}_{1}$ & $95.22(77.37)$ & $87.26(69.08)$ & $83.44(65.98)$ & $79.82(63.3)$ & $75.49(60.32)$ \\
\hline $\mathrm{G}_{3} \mathrm{C}_{2}$ & $96.69(79.60)$ & $91.08(72.62)$ & $86.27(68.25)$ & $83.32(65.89)$ & $79.85(63.32)$ \\
\hline $\mathrm{G}_{4} \mathrm{C}_{1}$ & $94.54(76.50)$ & $86.24(68.23)$ & $83.12(65.74)$ & $79.41(63.01)$ & $73.38(58.93)$ \\
\hline $\mathrm{G}_{4} \mathrm{C}_{2}$ & $96.07(78.58)$ & $90.15(71.70)$ & $85.66(67.75)$ & $82.69(65.41)$ & $77.76(61.80)$ \\
\hline Mean & 95.69 & 88.83 & 84.17 & 79.95 & 73.77 \\
\hline S.Em \pm & 0.16 & 0.03 & 0.02 & 0.14 & 0.05 \\
\hline $\mathrm{CD}$ at $1 \%$ & NS & 0.12 & 0.09 & 0.56 & 0.22 \\
\hline
\end{tabular}

Genotypes: $\mathrm{G}_{1}$ - RSFH-130; $\mathrm{G}_{2}-\mathrm{RSFH}-1887 ; \mathrm{G}_{3}-\mathrm{KBSH}-53 ; \mathrm{G}_{4}-\mathrm{KBSH}-44$

Containers: $\mathrm{C}_{1}$ - Cloth bag; $\mathrm{C}_{2}$ - Polythene bag

*The figures in the parenthesis are arc sine transformed

NS - Non - Significant 
Table.2 Effect of genotypes, containers and their interaction on seedling vigour index I of sunflower hybrids during storage

\begin{tabular}{|c|c|c|c|c|c|}
\hline \multirow{3}{*}{ Treatment } & \multicolumn{5}{|c|}{ Seeding vigour index I } \\
\hline & \multicolumn{5}{|c|}{ Storage period in months } \\
\hline & 2 & 4 & 6 & 8 & 10 \\
\hline \multicolumn{6}{|c|}{ Genotypes (G) } \\
\hline$\overline{\mathbf{G}_{1}}$ & 2418 & 1967 & 1822 & 1616 & 1042 \\
\hline $\mathbf{G}_{2}$ & 2620 & 2263 & 2056 & 1920 & 1443 \\
\hline$\overline{\mathbf{G}_{3}}$ & 2600 & 2107 & 1927 & 1839 & 1408 \\
\hline$\overline{\mathbf{G}_{4}}$ & 2489 & 2064 & 1920 & 1804 & 1341 \\
\hline Mean & 2532 & 2100 & 1931 & 1795 & 1308 \\
\hline S.Em \pm & 11.30 & 4.01 & 3.34 & 5.82 & 4.16 \\
\hline CD at $1 \%$ & 44.2 & 16.00 & 13.20 & 21.40 & 16.40 \\
\hline \multicolumn{6}{|c|}{ Containers (C) } \\
\hline$\overline{\mathrm{C}_{1}}$ & 2404 & 1968 & 1812 & 1653 & 1196 \\
\hline$\overline{\mathrm{C}_{2}}$ & 2659 & 2233 & 2051 & 1936 & 1421 \\
\hline Mean & 2532 & 2100 & 1931 & 1795 & 1308 \\
\hline S.Em \pm & 8.00 & 2.84 & 2.36 & 4.11 & 2.94 \\
\hline CD at $1 \%$ & 32.00 & 11.00 & 9.22 & 15.61 & 10.70 \\
\hline \multicolumn{6}{|c|}{ Interaction $(\mathrm{G} \times \mathrm{C})$} \\
\hline$\overline{\mathbf{G}_{1} \mathbf{C}_{1}}$ & 2301 & 1857 & 1690 & 1386 & 907 \\
\hline $\mathbf{G}_{1} \mathbf{C}_{2}$ & 2534 & 2077 & 1955 & 1847 & 1177 \\
\hline $\mathbf{G}_{2} \mathbf{C}_{1}$ & 2492 & 2130 & 1945 & 1808 & 1328 \\
\hline$\overline{\mathbf{G}_{2} \mathbf{C}_{2}}$ & 2747 & 2396 & 2168 & 2032 & 1559 \\
\hline $\mathbf{G}_{3} \mathbf{C}_{1}$ & 2480 & 1960 & 1819 & 1724 & 1298 \\
\hline $\mathbf{G}_{3} \mathrm{C}_{2}$ & 2721 & 2256 & 2037 & 1955 & 1518 \\
\hline $\mathbf{G}_{4} \mathbf{C}_{1}$ & 2342 & 1926 & 1795 & 1697 & 1253 \\
\hline$\overline{\mathbf{G}_{4} \mathbf{C}_{2}}$ & 2636 & 2203 & 2045 & 1913 & 1430 \\
\hline Mean & 2532 & 2100 & 1931 & 1795 & 1308 \\
\hline S.Em \pm & 16.09 & 5.70 & 5.03 & 6.67 & 5.96 \\
\hline $\mathrm{CD}$ at $1 \%$ & NS & 18.80 & 19.56 & 24.40 & 22.60 \\
\hline
\end{tabular}

Genotypes: $\mathrm{G}_{1}-\mathrm{RSFH}-130 ; \mathrm{G}_{2}-\mathrm{RSFH}-1887$; $\mathrm{G}_{3}$ - KBSH-53; G $4_{4}$ KBSH-44

Containers: $\mathrm{C}_{1}$ - Cloth bag; $\mathrm{C}_{2}$ - Polythene bag

NS - Non - Significant 
Table.3 Effect of genotypes, containers and their interaction on electrical conductivity $\left(\mathrm{dSm}^{-1}\right)$ of sunflower hybrids during storage

\begin{tabular}{|c|c|c|c|c|c|}
\hline \multirow{3}{*}{ Treatment } & \multicolumn{5}{|c|}{ Electrical conductivity $\left(\mathrm{dSm}^{-1}\right)$} \\
\hline & \multicolumn{5}{|c|}{ Storage period in months } \\
\hline & 2 & 4 & 6 & 8 & 10 \\
\hline \multicolumn{6}{|c|}{ Genotypes (G) } \\
\hline$\overline{\mathbf{G}_{1}}$ & 0.51 & 0.55 & 0.60 & 0.69 & 0.83 \\
\hline $\mathbf{G}_{2}$ & 0.45 & 0.49 & 0.53 & 0.66 & 0.75 \\
\hline $\mathbf{G}_{3}$ & 0.45 & 0.51 & 0.56 & 0.68 & 0.77 \\
\hline $\mathbf{G}_{4}$ & 0.48 & 0.55 & 0.58 & 0.68 & 0.81 \\
\hline Mean & 0.47 & 0.52 & 0.57 & 0.68 & 0.78 \\
\hline S.Em \pm & 0.008 & 0.002 & 0.004 & 0.001 & 0.001 \\
\hline CD at $1 \%$ & 0.03 & 0.008 & 0.01 & 0.003 & 0.003 \\
\hline \multicolumn{6}{|c|}{ Containers $(\mathrm{C})$} \\
\hline $\mathrm{C}_{1}$ & 0.51 & 0.54 & 0.59 & 0.69 & 0.80 \\
\hline $\mathrm{C}_{2}$ & 0.43 & 0.50 & 0.55 & 0.66 & 0.76 \\
\hline Mean & 0.47 & 0.52 & 0.57 & 0.68 & 0.78 \\
\hline S.Em \pm & 0.006 & 0.001 & 0.003 & 0.001 & 0.0009 \\
\hline CD at $1 \%$ & 0.02 & 0.004 & 0.01 & 0.002 & 0.003 \\
\hline \multicolumn{6}{|c|}{ Interaction $(\mathrm{G} \times \mathrm{C})$} \\
\hline $\mathrm{G}_{1} \mathrm{C}_{1}$ & 0.54 & 0.57 & 0.63 & 0.71 & 0.85 \\
\hline $\mathbf{G}_{1} \mathbf{C}_{2}$ & 0.48 & 0.53 & 0.58 & 0.68 & 0.81 \\
\hline $\mathbf{G}_{2} \mathbf{C}_{1}$ & 0.48 & 0.51 & 0.55 & 0.67 & 0.78 \\
\hline $\mathbf{G}_{2} \mathbf{C}_{2}$ & 0.41 & 0.47 & 0.52 & 0.65 & 0.72 \\
\hline $\mathbf{G}_{3} \mathbf{C}_{1}$ & 0.50 & 0.54 & 0.58 & 0.70 & 0.79 \\
\hline $\mathbf{G}_{3} \mathbf{C}_{2}$ & 0.42 & 0.48 & 0.55 & 0.66 & 0.74 \\
\hline $\mathbf{G}_{4} \mathbf{C}_{1}$ & 0.52 & 0.56 & 0.62 & 0.70 & 0.81 \\
\hline $\mathrm{G}_{4} \mathrm{C}_{2}$ & 0.43 & 0.53 & 0.55 & 0.67 & 0.80 \\
\hline Mean & 0.47 & 0.52 & 0.57 & 0.68 & 0.78 \\
\hline S.Em \pm & 0.01 & 0.002 & 0.005 & 0.001 & 0.002 \\
\hline CD at $1 \%$ & NS & 0.007 & 0.023 & 0.004 & 0.008 \\
\hline
\end{tabular}

Genotypes: $\mathrm{G}_{1}$ - RSFH-130; $\mathrm{G}_{2}$ - RSFH-1887; G $3^{-}$KBSH-53; G $4^{-}$KBSH-44

Containers: $\mathrm{C}_{1}$ - Cloth bag; $\mathrm{C}_{2}$ - Polythene bag

NS - Non - Significant

\section{Containers (C)}

Seedling vigour index I differed significantly among all the containers for all the storage months. In the second month of storage, highest seedling vigour index I was seen in $\mathrm{C}_{2}$ (2659) and minimum seedling vigour was seen in $\mathrm{C}_{1}$ (2404). The decreasing trend of seedling vigour was seen as the storage period prolonged. At the end of 10 months, highest Seedling vigour I was seen in Polythene bag (700 gauge) (1421) and minimum was seen in Cloth bag $\left(\mathrm{C}_{1}\right)$ 1196. Reduction of seedling vigour index was always greater in seeds stored in cloth bag, which is mainly due to increased seed deterioration and decreased seedling vigour index due to loss of viability has been observed in barley (Abdul Baki and 
Anderson, 1973). Lowest vigour was obtained from cloth bag for all storage periods, which might be due to high moisture and fungi infestation (Singh and Dadlani, 2003).

\section{Interaction between genotypes and containers $(\mathbf{G} \times \mathbf{C})$}

The seedling vigor index I decreased significantly with increase in storage period except for first two months. Initially, highest seedling vigour index $\mathrm{I}$ was seen in $\mathrm{G}_{2} \mathrm{C}_{2}$ (2747) which was followed by $\mathrm{G}_{3} \mathrm{C}_{2}$ (2721) and minimum seedling vigour index $\mathrm{I}$ was seen in $\mathrm{G}_{1} \mathrm{C}_{1}$ (2301).

At the end of 10 months $\mathrm{G}_{2} \mathrm{C}_{2}$ recorded highest seedling vigour index I (1559) which was followed by $\mathrm{G}_{3} \mathrm{C}_{2}$ (1518) and lowest was seen in $\mathrm{G}_{1} \mathrm{C}_{1}$ (907) RSFH- 130 stored in cloth bag showed lowest seedling vigour and RSFH-1887 stored in polythene bag showed highest seedling vigour index I.

This effect can be attributed to the reason that with the passing of storage period, vigour of seed decline due to catabolic activity going in the seed and thus the seed though viable yet fails to emerge. Similar observations are made by Gujar et al., (2001) in China aster seeds, Yogeesha et al., (2004) and Arulnandhy and Senanayake (1991) in soybean.

\section{Electrical conductivity $\left(\mathrm{dSm}^{-1}\right)$}

The results on Electrical conductivity of seed leachate during the storage period as influenced by different genotypes and packaging materials are depicted in Table 3.

The Electrical conductivity of seed leachate increased progressively with advancement of storage period irrespective of the genotypes, storage containers and their interactions. The mean value of the seed lechate increased from 0.47 to $0.78 \mathrm{dSm}^{-1}$ at the end of 10 months.

\section{Genotypes (G)}

Significant results were seen during all the 10 months of storage irrespective of genotypes. The minimum EC value was observed in $\mathrm{G}_{2}$ $\left(0.45 \mathrm{dSm}^{-1}\right)$ which was on par with $\mathrm{G}_{3}(0.45)$ and maximum EC value was seen in $\mathrm{G}_{1}(0.51$ $\mathrm{dSm}^{-1}$ ). Whereas, $\mathrm{G}_{4}$ showed EC of 0.48 . This trend was followed till 10 months where $G_{2}$ maintained minimum EC value of $(0.75$ $\mathrm{dSm}^{-1}$ ) and $\mathrm{G}_{1}$ showed maximum EC value of $0.83 \mathrm{dSm}^{-1}$. This may be due to the Physical injury to the seeds, seed size adversely affect the electrical conductivity test results (Loeffeler et al., 1988). The difference in the electrical conductivity among the genotypes may be because RSFH-130 may be susceptible to field weathering causing reduction in seed membrane integrity at warmer sites and probably due to inherent qualities of varieties such as seed size and may be weaker seed coat properties, Chirchir (2015).

\section{Containers (C)}

Electrical conductivity of seed leachate differed significantly among the storage containers at all the months of storage. Initially, $\mathrm{C}_{2}$ showed minimum Electrical conductivity $\left(0.43 \mathrm{dSm}^{-1}\right)$ and $\mathrm{C}_{1}$ showed maximum EC $\left(0.51 \mathrm{dSm}^{-1}\right)$. At the end of $10^{\text {th }}$ month, $\mathrm{G}_{2}$ showed EC value of $0.76 \mathrm{dSm}^{-1}$ which found to be lesser then $C_{1}(0.80)$. The negative relationship between $\mathrm{EC}$ and seed germination indicated that more cells leachate escaped from low quality seed and lowered the germination capacity of sunflower seed, which is in agreement with the findings of Halim et al., (2012) in onion seeds. High EC of seed is assumed due to membrane deterioration during the imbibition period of lower quality seeds. The vigour of cloth bag's seed was decreased over time of storage due to greater moisture absorption (Abdul-Baki and Anderson, 1973). The variation noticed in 
two containers like cloth and polythene bag may be due to structural differences, permeability of membrane and cellular membrane deterioration.

\section{Interaction between genotypes and containers $(\mathbf{G} \times \mathbf{C})$}

Interaction between Genotypes and containers differed significantly on Electrical conductivity of seed leachate in all months of storage except $2^{\text {nd }}$ month of storage.

The seeds of RSFH-1887, stored in polythene bag of 700 guage $\left(\mathrm{G}_{2} \mathrm{C}_{2}\right)$ showed significantly lesser EC of $0.41 \mathrm{dSm}^{-1}$, which was followed by $\mathrm{G}_{3}\left(0.42 \mathrm{dSm}^{-1}\right)$ and maximum was seen in RSFH-130 seeds stored in cloth bag (0.54 $\left.\mathrm{dSm}^{-1}\right)$. Similar order was seen till the end of $10^{\text {th }}$ month, where $\mathrm{G}_{2} \mathrm{C}_{2}$ maintained minimum EC value of, $0.72 \mathrm{dSm}^{-1}$ and maximum EC value was seen in $\mathrm{G}_{1} \mathrm{C}_{1}\left(0.85 \mathrm{dSm}^{-1}\right)$.

This indicates that, progressive increase in EC in $\mathrm{G}_{1} \mathrm{C}_{1}$ may be due to the genotypic variations and its susceptibility to the membrane damage as influenced by packaging materials (Natraj, 2008).

Results from the present study suggest that the sunflower genotype differences affect germinability and storability here each genotype behaved differently during storage. The sunflower seeds generally deteriorated with storage and deterioration of the seeds was particularly strong for seeds stored in cloth bag. High temperature, high relative humidity, and moisture in the storage environment are the principal factors involved in deterioration of sunflower seed quality during storage.

The seeds of RSFH-1887 can be stored for long duration which was followed by $\mathrm{KBSH}$ 53 and RSFH-130 was found to be the poor storer compared to other hybrids. It can also be concluded that the seed stored in polythene bag (700 guage) shows highest germination and vigour compared to cloth bag irrespective of genotypes.

\section{References}

Abdul-Baki, A. A. and Anderson, J. D., 1973, Vigour determination in soybean seeds by multiple criteria. Crop Sci., 13: 630633.

Ankaiah, R., Manohar, R. N., Radhika, K. and Meena Kumari, K. V. S., 2006, Effect of containers on storability of tomato seed (Lycopersian esculentum L.) under ambient condition, Proc. Of XII Nat. Seed Seminar at ANGRAU, Hyderabad during 24-26 Feb., pp.60.

Arulnandhy, A. and Senanayake, V. D. A., 1991, Deterioration of soybean seed stored in different under ambient condition. Seed Res., 16: 183-192

Bhattacharya, P., Samui, R. C. and Sen, S., 1983, Studies on the germination and viability of stored sunflower seed. Seed Res., 11: 162-171.

Chirchir, 2015, Seed quality of soybean (Glycine max [L.] Merrill) genotypes under varying storage and priming methods, mother plant nutrient profiles and agro-ecologies in Kenya, M.Sc. Thesis, University of Agriculture and Enterprise Development, Kenyatta.

Demirkaya, M., Dietz, K. J. and Sivritepe, H. O., 2010, Changes in antioxidant enzymes during aging of onion seeds. Notulae Botanicae Horti. Agrobotanici, 38(1): 49-52.

Ewart, A. J., 1908. On the longevity of seeds. Proc. Rev. Soc. Vict., 21: 1-20.

Gujar, A. R., Nimbalkar, C. A. and Dumber, P. S.S, 2001, Studies on viability of China Aster seed. J. Maharashtra Agric. Univ., 26 (1): 77-79.

Iqbal, N. A., Shahzad, M., Basra, and Khalil, U. R., 2002, Evaluation of Vigor and 
Oil Quality in Cottonseed during Accelerated Aging. Int. J. Agri. Biol., 4(3), 318-322.

ISTA, 1999, International rules for seed testing. Seed Sci. \& Technol., 21 (Suppl): 1-228.

ISTA, 2013, International Rules of Seed Testing. Seed Sci. Technol., 27: 25-30.

Loeffler, T. M., Tekrony, D. M. and Egli, D. B., 1988, The bulk conductivity test as an indicator of soybean seed quality. Seed Technol., 12: 37-53.

Milosevic, M. M., Vujakovic, D. and Karagic, 2010, Vigour tests as indicators of seed viability. Genetika, 42(1): 103-118.

Mote V. N., Mohite, A. P. and Lolage, G. R., 1995, Effect of storage periods and storage containers of imidacloprid treated sorghum seeds against shootfly and seed germination. Pestology, 19 (94): 10-13.

Muhammad, A., 2008, Effect of Planting Dates and Storage on Yield and Quality of Indigenous Land Races and Improved Varieties of Soyabean, Ph.D. Thesis, Agric. Uni. Peshawar, Pakistan.

Nataraj, K., 2008, Studies on storability of promising hybrids seeds of sunflower (Helianthus annuus L.). M.Sc. (Agri.) Thesis, Univ. of Agric. Sci., Bangalore.

Panse, V. G. and Sukhatme, P. V., 1967, Statistical Methods for Agricultural Workers, Indian Council of Agricultural Research, New Delhi, pp. 167-174.
Reuzeau, C. and Cavalie, G., 1995, Activities of free radical processing enzymes in dry sunflower seeds. New Phytol., 30: 59-66.

Ruzrokh, M., Golozani, K. G. and Javanshir, A., 2003, Relationship between seed vigor with growth and yield in pea (Cicer arietinum L). Nahal O Bazr., 18: 156-169.

Sharma, S., Virdi, P., Gambhir, S. and Munshi, S. K., 2006, J. Res. Punjabi Agric. Univ., 43: 29-33.

Simic, B., Sudaric, A., livic, I., Kalinovic, I., Rozman, V. and Cosic, J., 2006, Influence of storage conditions on seed quality of Maize, Soybean and Sunflower. Proceedings of the $9^{\text {th }}$ International Working Conference on Stored product Protection, Campinas, Sao Paolo, Brazil, 59-63.

Singh, K. K. and Dadalni, M., 2003, Effect of packaging on vigour and viability of soybean [Glycine max (L.) Merrill] seed during ambient storage. Seed res., 31(1): 27-32.

Tekrony, D. M. and Egli, D. B., 1993, Seedbed Conditions and Prediction of Field Emergence of Soybean Seed. Seed Sci. and Technol., 21: 127-137.

Yogeesha, H. S., Janakiram, T., Bhanuprakash, K. and Naik, L. B. 2004, Storage studies in China aster. $J$. Orn. Hrt., 7 (3-4): 128-131.

\section{How to cite this article:}

Surekha, J.A., Vijaykumar Kurnalliker, N.M. Shakuntala, Vikas Kulkarni, S.M. Prashant and Mukesh Kumar Meena. 2018. Studies on Storability of Elite Hybrids of Sunflower. Int.J.Curr.Microbiol.App.Sci. 7(10): 1708-1717. doi: https://doi.org/10.20546/ijcmas.2018.710.196 